\title{
Estimation of modulation transfer function for the Vietnamese satellite VNREDSat-1 by using the permanent test site
}

\author{
M. N. Nguyen ${ }^{1,2}$, V.A. Tran ${ }^{2}$, V. T. Nghiem ${ }^{3}$, T. P. T. Do ${ }^{2}$, X. H. Chu ${ }^{1}$, L. H. Trinh ${ }^{4}$ \\ ${ }^{1}$ Space Technology Institute of Vietnam Academy of Science and Technology \\ Hanoi, Vietnam \\ E-mail:nmngoc@sti.vast.vn \\ ${ }^{2}$ Hanoi University of Mining and Geology, Hanoi, Vietnam \\ ${ }^{3}$ National Remote Sensing Department, Hanoi, Vietnam \\ ${ }^{4}$ Le Quy Don Technical University, Hanoi, Vietnam
}

\begin{abstract}
Modulation transfer function (MTF) is the magnitude response of an optical system to sinusoids of different spatial frequencies, it is defined as the normalization of the Fourier transform of the Point Spread Function (PSF). MTF is not only an important factor in evaluating image quality but also an indicator to estimate the performance of payload on optical remote sensing satellite, especially for high spatial resolution small satellites. The data used in the analysis are from VNREDSat-1 launched on May 7, 2013, and they are in 2.5-meter ground sample distance (GSD) in the panchromatic band. The classical slant-edge method for permanent test site is used to estimate MTF, thereby evaluating the VNREDSat-1 performance. The archived results proved that image quality has been ensured during the designed life of 5 years; moreover, those are also the basis for Vietnam to finalize regulations in terms of validation and calibration for optical remote sensing satellite since it has its own test site.
\end{abstract}

Keywords: MTF, image quality, VNREDSat-1, test site, small satellite

\section{Introduction}

Data quality is one of the essential factors in evaluating optical remote sensing system performance, or to be more accurate, as payload (SPOT..., 2004; Valorge et al., 2004). The users usually need spatial resolution, temporal resolution, spectral resolution, and radiant resolution; however, these parameters only partially illustrate payload performance.

Payload performance is usually assessed in three periods: in the laboratory, in-orbit test (IOT), and in operation phase. During the operation, the payload is affected by changing attitude, fly dynamics activities, equipment lifetime, its activities, atmospheric, etc. that lead to changes in optical design and image quality, which is different from the laboratory tests (Gascon et al., 2017; Wenny et al., 2015).

For small satellites like VNREDSat-1, due to dimension and weight limitations, the optical system is designed with a complicated mirrors system (Luquet et al., 2008; Nguyen et al., 2018). This, therefore, leads to a physical structure of the instrument that is much more affected during launch as well as operation in the orbit, hence the changes in image quality over the satellite uptime.

The Vietnam's satellite, VNREDSat-1, was launched in 2013 with a design lifetime of 5 years. However, based on technical reports and reality operations, it is still in good condition. In order to prove this, the payload quality, a key parameter of a remote sensing satellite, was considered. This study sets the path for deeper studies such as image simulation of the future remote sensing satellite, proves that it is necessary to have separate test sites for control and be more proactive in terms of assessment and periodical image quality test.

VNREDSat-1 was designed using Astrium's platform generation AstroSat100, and the instrument was NAOMI-125, a multispectral imager with high spatial resolution, $2.5 \mathrm{~m}$ for panchromatic band and $10 \mathrm{~m}$ for multispectral band. In NAOMI-125, the optical system, one of the most important components, was made based on Korsch Three-Mirror Anastigmatic design to ensure compactness and to deliver good optical quality with three aspheric mirrors and two folding mirrors (Nguyen et al., 2018; https://directory.eoportal.org/web/eoportal/satellite-missions/v-w-X-y-z/vnredsat-1). 
MTF is an essential parameter and it is usually utilized to ensure that the vibration in the launching phase, the process of moving from atmosphere to space, operation phase, and thermal condition do not interfere with the payload quality causing changes in the image quality (Kumar et al., 2006).

Thus, the estimation of MTF in assessing the payload performance of a satellite is necessary (SPOT..., 2004). Moreover, since VNREDSat-1 is the first remote sensing satellite in Vietnam, this estimation lays the foundation for further finalizing the regulations for calibration and validation to ensure image quality during satellite operation and exploitation.

\section{Data and Methodology}

\section{Data}

This study used VNREDSat-1 images in the panchromatic band, $2.5 \mathrm{~m}$ spatial resolution, and small viewing angle. To ensure the consistency as well as objectivity in terms of the test site, all data were captured in the Salon de Provence, France. This test site was used to assess payload performance in the in-orbit test phase (IOT) and later years (Table 1).
Table 1. Used data

\begin{tabular}{c|c}
\hline No. & Date \\
\hline 1 & 10.07 .2015 \\
\hline 2 & 25.04 .2016 \\
\hline 3 & 07.08 .2017 \\
\hline 4 & 20.04 .2018 \\
\hline 5 & 25.07 .2019 \\
\hline
\end{tabular}

\section{Methodology}

There are several methods to estimate MTF such as using test sites, using bi-resolution, using specific equipment on board, and direct or indirect parameter model (Blanc, Wald, 2009; Gascon et al., 2017; Kohm, 2004; Nghiem et al., 2018; SPOT..., 2004; Viallefont, 2003). The most commonly used method is using test sites, and they can be divided into four types: edge, pulse, impulse, and periodic test site (Blanc, Wald, 2009; Helder et al., 2003; Léger et al., 2004; Li et al., 2016).

The edge test site method is also called the edge method, knife-edge method, or slant-edge method. It is used commonly in the laboratory and can be applied in many different ways. In order to estimate MTF by the edge method, the test site is designed like in Fig. 1 (Blanc, Wald, 2009; Léger et al., 2004; Viallefont, Léger, 2010; Wenny et al., 2015). For an edge test site, not only artificial sites are used but often places with high contrast between the black box and the white box such as fields, car park, the boundary between building and ground, the boundary between water and ice or bridges spanning rivers, bays, etc.

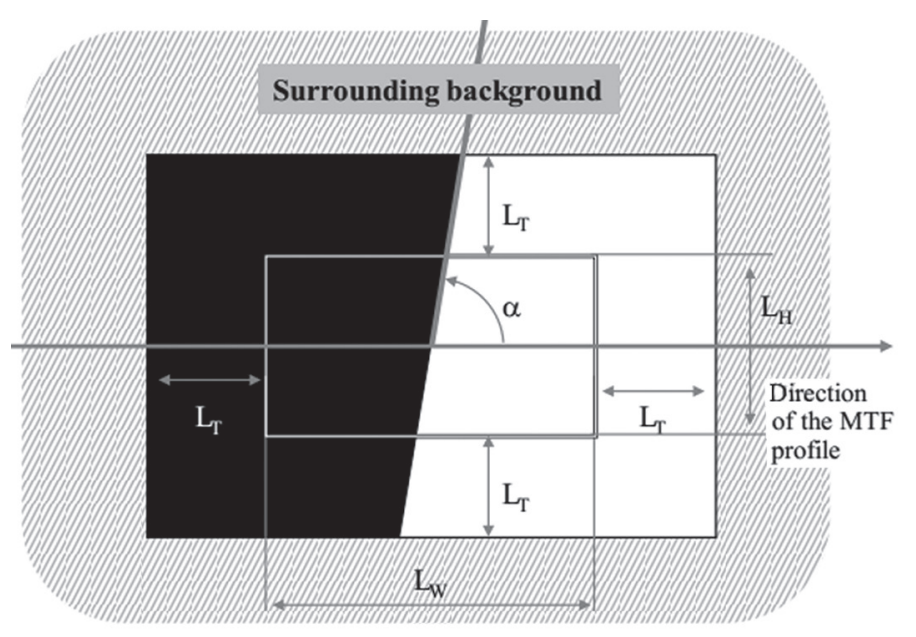

Fig. 1. The edge test site schematic

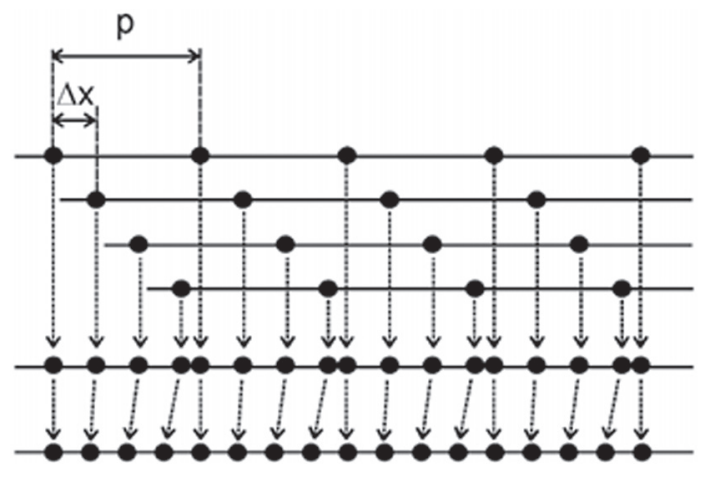

Fig. 2. The sampling grid 
In the VNREDSat-1 IOT phase, MTF was estimated using the Salon de Provence test site, which has a high contrast Heaviside edge.

The MTF of an optical system is determined by the interpolation from the measured MTF value at a given spatial frequency; in this case, it is the Nyquist frequency (Boreman, 2001). This method is commonly referred to as the method that utilizes the Fourier transform of the Line Spread Function (LSF) or the Edge Spread Function (ESF).

In this method, it is vital to define a group of $\mathrm{N}$ consecutive image rows to reconstruct the ESF, then superimposition sampling of the $N$ image rows in the following way: pixel 1 of row 1 is followed by pixel 1 of row 2 , so on up to pixel 1 of row $N$, then pixel 2 of row 1, pixel 2 of row 2, and pixel 2 of row $N$ until the last row. This process is performed as shown in Fig. 2 (see p. 82).

The number of image rows taken on an edge is given by:

$$
N=\frac{p}{\Delta x}
$$

From the regenerated ESF, the LSF row propagation function can be obtained by performing a finite element differential of the ESF function. Next, an MTF can be obtained by taking the Fourier Transform on LSF.

The relationship between the ESF, LSF, and MTF is shown as follows:

$$
\mathrm{ESF} \stackrel{\text { Finite elelment differetial }}{\longrightarrow} \mathrm{LSF} \stackrel{\text { Fourier transform }}{\longrightarrow} \text { MTF }
$$

\section{Results and Discussion}

In each scene of the test site, we took samples of about 4-5 rows or columns, and the sampling position had about 25-30 pixels so that the sampling area was least affected by the surrounding areas. The sampling areas were taken from white box to black box and black box to white box (Fig. 3) and in two directions: along-track and across-track.

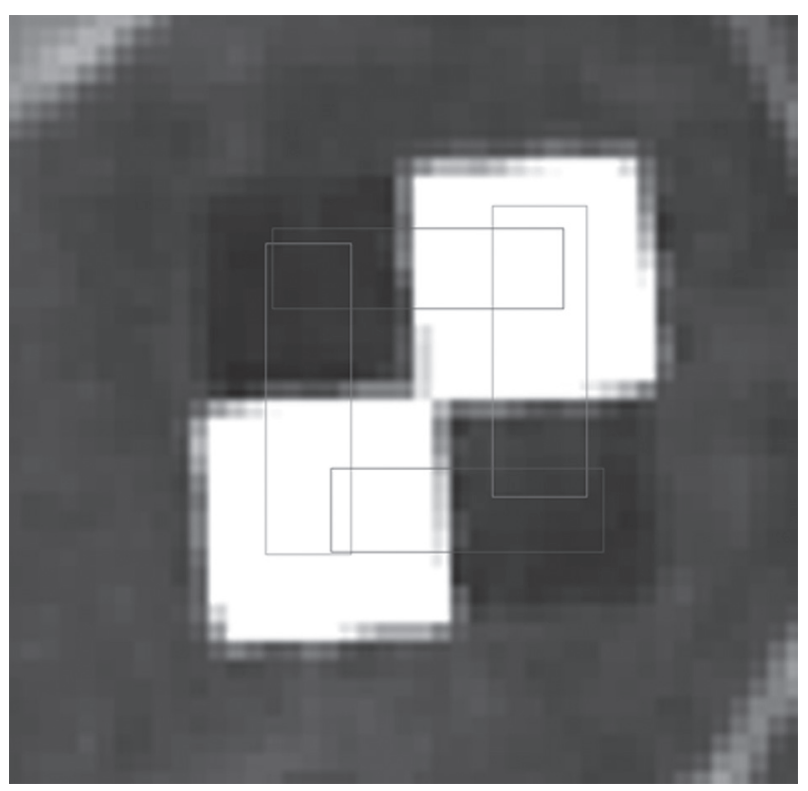

Fig. 3. Sampling areas

\section{Along-track results}

In time-series images of the test site, we conducted sampling in both directions to alternate the state of the test site from black box to white box and vice versa. The results are presented in Tables 2 and 3. 
Table 2. Along-track results, the transition from black box to white box

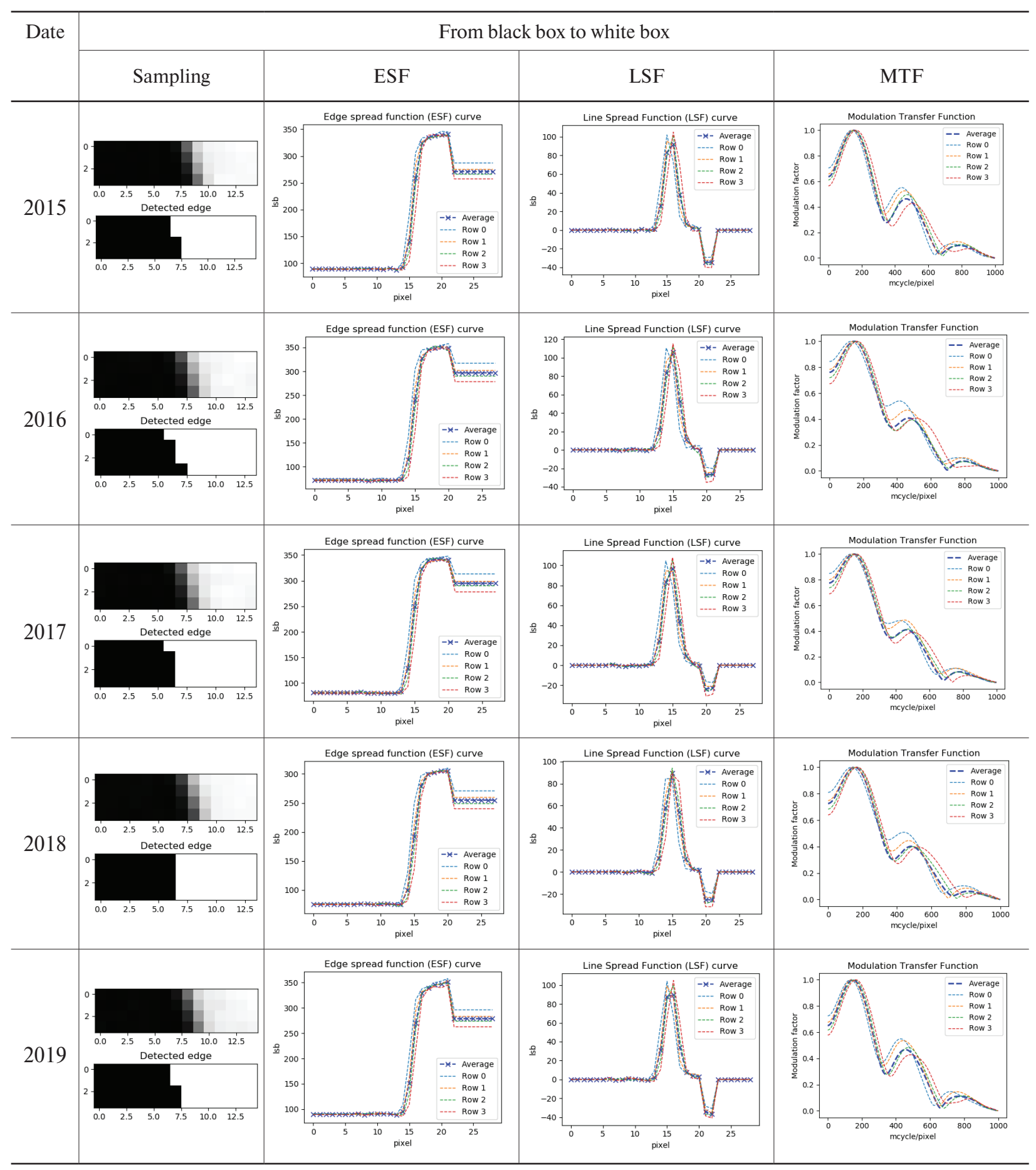


Table 3. Along-track results, the transition from white box to black box

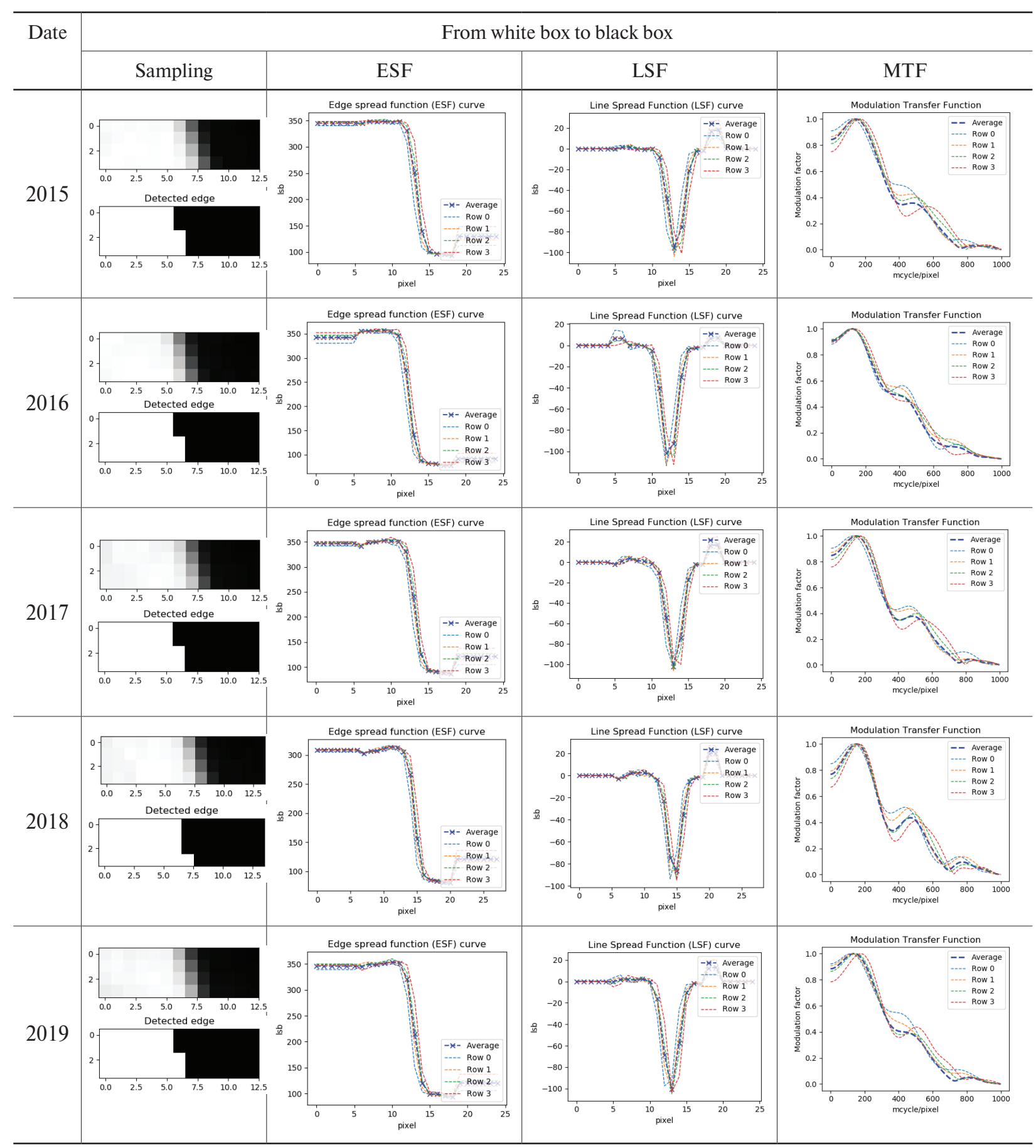

Table 4. MTF along-track

\begin{tabular}{c|c|c|c}
\hline \multirow{2}{*}{ Date } & \multicolumn{2}{|c}{ MTF } \\
\cline { 2 - 4 } & Black box to white box & White box to black box & Average \\
\hline 10.07 .2015 & 0.22 & 0.24 & 0.23 \\
\hline 25.04 .2016 & 0.23 & 0.16 & 0.19 \\
\hline 07.08 .2017 & 0.20 & 0.24 & 0.22 \\
\hline 20.04 .2018 & 0.25 & 0.21 & 0.23 \\
\hline 25.07 .2019 & 0.20 & 0.21 & 0.21 \\
\hline
\end{tabular}


The estimated MTF is received along-track with both transitions, from white box to black box and from black box to white box (Table 4).

The lowest MTF value along-track is 0.16 for the transition from white to black in the image of 2016 because the contrast is not high enough between the black box and the white box. The highest MTF is 0.25 for the transition from black to white in the image of 2018.

\section{Across-track results}

Similar to along-track, the results across-track are shown in Tables 5 and 6.

Table 5. Across-track results, the transition from black box to white box

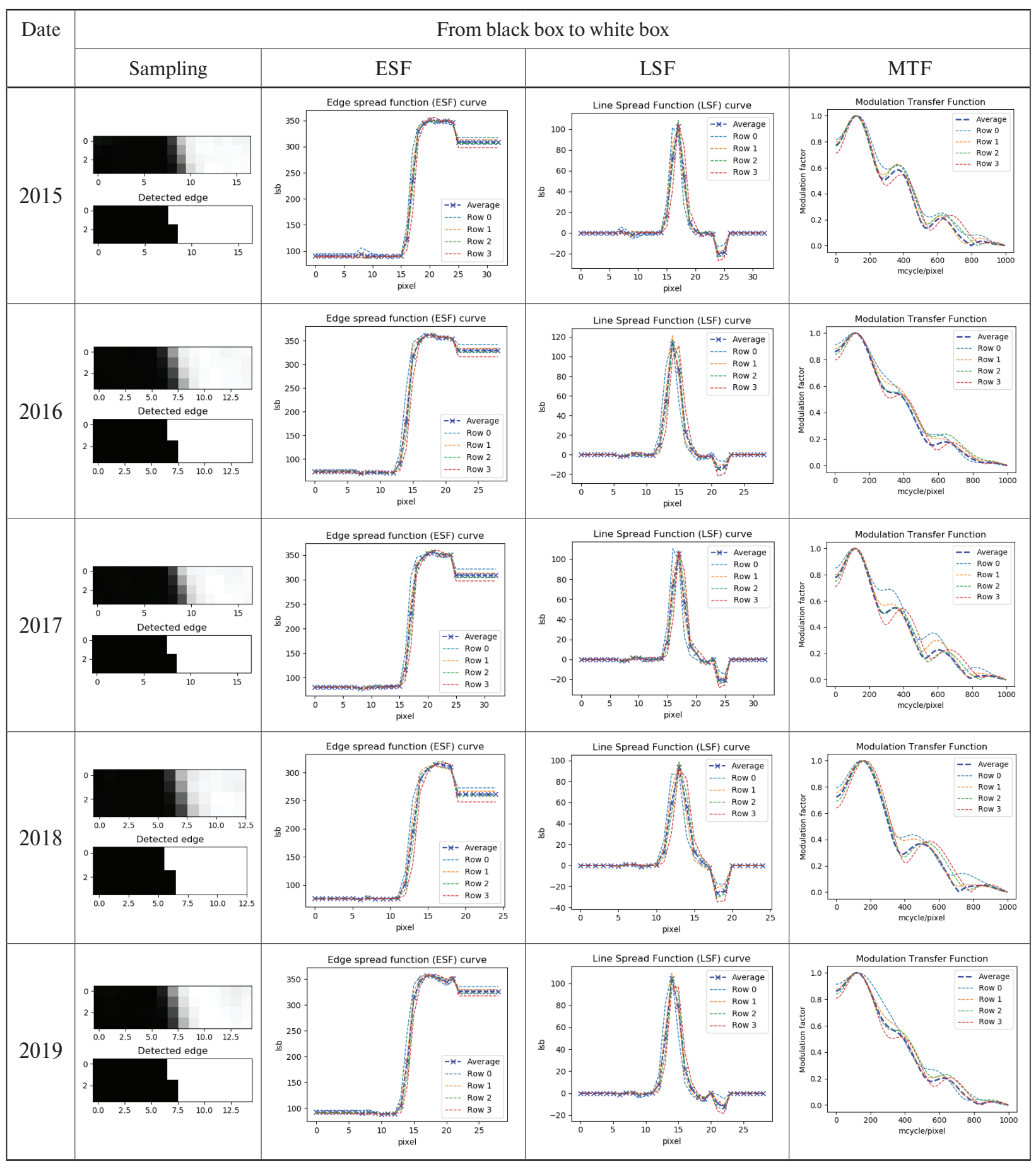


Table 6. Across-track results, the transition from white box to black box

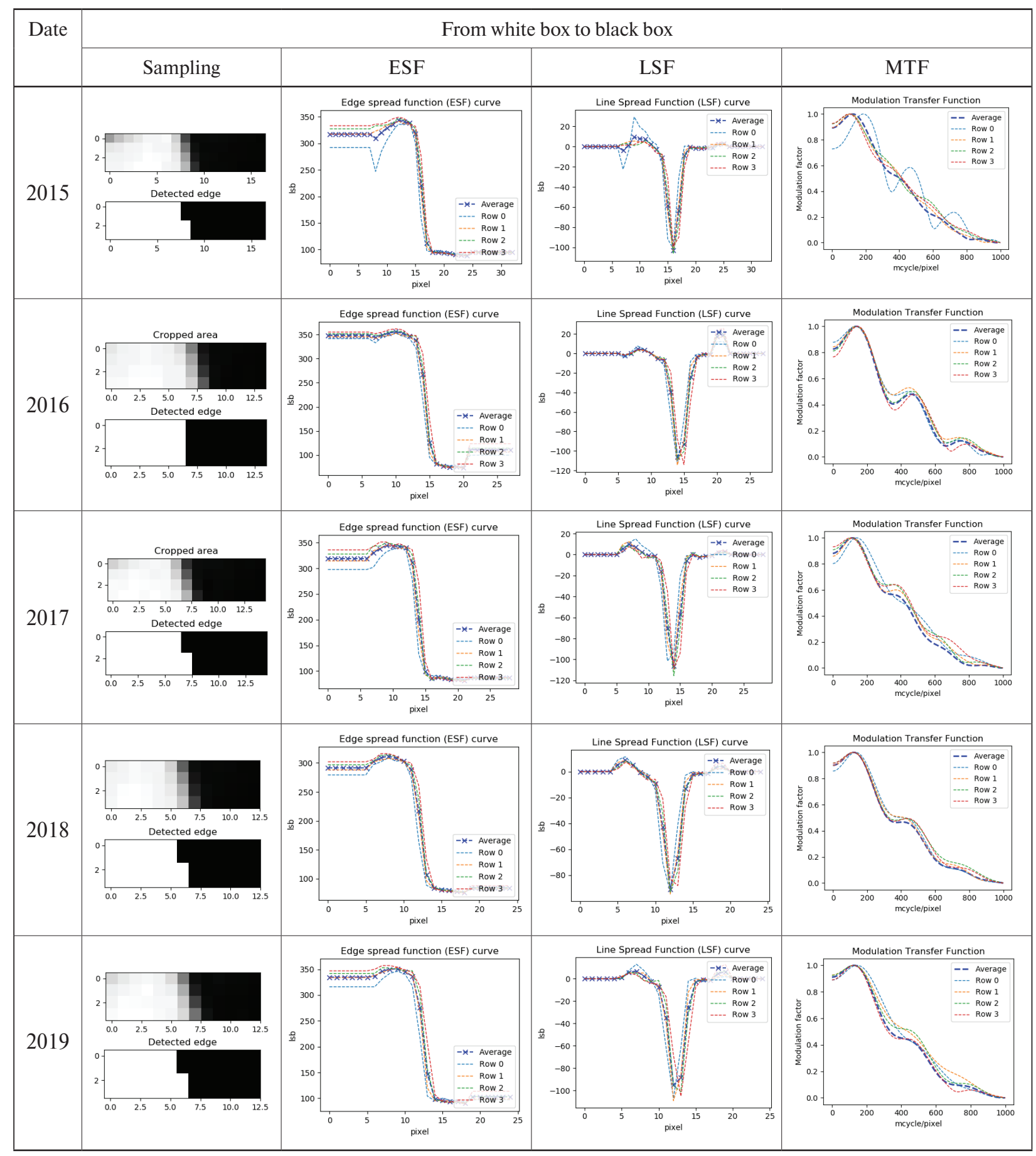

Table 7. MTF across-track

\begin{tabular}{c|c|c|c}
\hline \multirow{2}{*}{ Date } & \multicolumn{2}{|c}{ MTF } \\
\cline { 2 - 4 } & Black box to white box & White box to black box & Average \\
\hline 10.07 .2015 & 0.19 & 0.22 & 0.21 \\
\hline 25.04 .2016 & 0.16 & 0.20 & 0.18 \\
\hline 07.08 .2017 & 0.22 & 0.19 & 0.21 \\
\hline 20.04 .2018 & 0.27 & 0.19 & 0.23 \\
\hline 25.07 .2019 & 0.19 & 0.21 & 0.20 \\
\hline
\end{tabular}




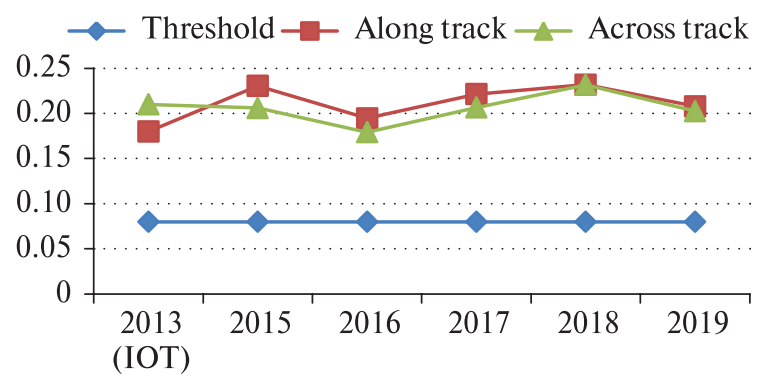

Fig. 4. Estimated MTF and Specified threshold

The estimated MTF received across-track for both transitions, from white box to black box and black box to white box in shown in Table 7.

The MTFs across-track are quite uniform and do not have large variations, but the lowest value also fell in 2016, similar to the along-track results.

The MTF at IOT phase, the time series data and their respective viewing angles were compared so as to check the impact of viewing angles on MTF estimation.

Table 8 shows that the viewing angle did not affect the contrast on the test site, because most of the imaging was performed at low viewing angles (below $15^{\circ}$ ), far beyond glare condition. During the satellite lifetime (5 years, 2013-2018) and more, the MTF value was approximately 0.2 and always stayed above the specified threshold $(>0.08)$ (Nghiem, 2017). This indicates that the contrast and sharpness of image data are guaranteed, or in other words, the image quality of the VNREDSat-1 satellite system is always at a good level.

Table 8. Comparison of MTF in time-series and respective viewing angles

\begin{tabular}{c|c|c|c|c}
\hline Date & Viewing across-track, deg & Viewing along-track, deg & Along-track & Across-track \\
\hline$I O T(2013)$ & 2.65 & 5.16 & 0.18 & 0.21 \\
\hline 10.07 .2015 & 14.07 & 0.68 & 0.23 & 0.21 \\
\hline 25.04 .2016 & 13.60 & 0.64 & 0.19 & 0.18 \\
\hline 07.08 .2017 & 2.84 & 0.16 & 0.22 & 0.21 \\
\hline 20.04 .2018 & 14.3 & 0.71 & 0.23 & 0.23 \\
\hline 25.07 .2019 & 7.83 & 0.35 & 0.21 & 0.20 \\
\hline
\end{tabular}

Besides, the sampling and the number of samples will have a significant influence on the obtained results. The MTF value will be higher if the sampling window is small because the number of samples is small and they are uniform easily, which leads to a high contrast between black and white boxes. But then the results will not express the full capabilities of the payload.

When the test site in the Buon Ma Thuot city, Vietnam, was built, we tried to use it for MTF estimation by the same method. The images were collected in 2017 and 2018 and the results were satisfactory (Table 9, Fig. 4).

Table 9. Estimated MTF using Buon Ma Thuot test site

\begin{tabular}{c|c|c|c}
\hline Date & Black box to white box & White box to black box & Average \\
\hline & \multicolumn{3}{|c}{ MTF in along-track } \\
\hline 2017 & 0.29 & 0.20 & 0.24 \\
\hline 2018 & 0.19 & 0.21 & 0.20 \\
\hline 2017 & 0.18 & 0.19 & 0.18 \\
\hline 2018 & 0.11 & 0.20 & 0.16 \\
\hline
\end{tabular}

The lowest MTF value is 0.11 , however, it is still higher than the threshold value of 0.08 . The average MTF is still approximately 0.2 (0.21 in 2017 and 0.18 in 2018), similar to Salon de Provence test site. This indicates that Buon Ma Thuot test site can be used for VNREDSat-1 MTF estimation. Moreover, the reflectance percentage could be measured in situ before taking an image to estimate MTF or other parameters assessment. 


\section{Conclusion}

The average value of MTF during 5 years of operation is approximately 0.2 , which states that the image quality of VNREDSat-1 is guaranteed until the calculation time. The sampling window is determined such that the maximum number of possible samples is used to express the full payload performance through the MTF; at the same time, the samples should be as homogeneous as possible. However, the fact that the test site's reflectance percentage has not been collected before taking images also partly affects the objectivity of the results.

The edge method is widely used in many places and for many different types of satellites. Although there are various methods to estimate MTF for satellites with high spatial resolution, this remains the most optimal method, especially in Vietnam, when we have built the edge test site in the Buon Ma Thuot city.

The results have contributed to further improve the operation process of a complete Earth observation satellite system. At the same time, it is also the basis for opening new research such as simulation of future satellite image data with parameters designed according to users' requirements.

This study could not have been completed without the support from Space Technology Institute, Vietnam Academy of Science and Technology; and Vietnam Ground Station, Department of National Remote Sensing.

\section{References}

1. Blanc P., Wald L., A review of earth-viewing methods for in-flight assessment of modulation transfer function and noise of optical spaceborne sensors, HAL, 2009, 39 p., Id. hal-00745076, available at: https://halmines-paristech.archives-ouvertes.fr/hal-00745076.

2. Boreman G. D., Modulation Transfer Function in Optical and Electro-Optical Systems, SPIE Press, 2001, 123 p., available at: https://doi.org/10.1117/3.419857.

3. Gascon F., Bouzinac C., Thépaut O., Jung M., Francesconi B., Louis J., Lonjou V., Lafrance B., Massera S., Gaudel V.A., Languille F., Alhammoud B., Viallefont F., Pflug B., Bieniar J., Clerc S., Pessiot L., Trémas T., Cadau E., Bonis D. R., Isola C., Martimort P., Fernandez V., Copernicus Sentinel-2A calibration and products validation status, Remote Sensing, 2017, Vol. 9, Issue 6, Art. No. 584, 81 p., available at: https://doi.org/10.3390/rs9060584.

4. Helder D., Choi T., Rangaswamy M., In-flight characterization of spatial quality of remote sensing imaging systems using point spread function estimation, Post-Launch Calibration of Satellite Sensors: Proc. Intern. Workshop on Radiometric and Geometric Calibration, 2-5 Dec. 2003, Gulfport, Mississippi, USA, S. A. Morain, A. M. Budge (eds.), London: CRC Press, 2004, pp. 151-170.

5. Kohm K., Modulation transfer function measurement method and results from Obrbview-3 high resolution imaging satellite, Proc. ISPRS 2004, Istabul, Turkey, 2004, 6 p.

6. Kumar A.S., Manjunath A.S., Rao K. M. M., Kumar A.S. K., Navalgund R. R., Radhakrishnan K., On-orbit spatial resolution estimation of IRS: CARTOSAT-1 Cameras with images of artificial and manmade targets-Preliminary results, Proc. SPIE, 2006, Vol. 6405, 64050W-1, 7 p., available at: https://doi. org/10.1117/12.697001.

7. Léger D., Déliot P., Valorge C., On-orbit MTF assessment of satellite cameras, Post-Launch Calibration of Satellite Sensors: Proc. Intern. Workshop on Radiometric and Geometric Calibration, 2-5 Dec. 2003, Gulfport, Mississippi, USA, S. A. Morain, A. M. Budge (eds.), London: CRC Press, 2004, pp. 67-76.

8. Li H., Yan C., Shao J., Measurement of the Modulation Transfer Function of infrared imaging system by Modified Slant edge method, J. Optical Society of Korea, 2016, Vol. 20, No. 3, pp. 381-388, DOI: 10.3807/ JOSK.2016.20.3.381.

9. Luquet P., Chikouche A., Benbouzid A. B., Arnoux J.J., Chinal E., Massol C., Rouchit P., de Zotti S., NAOMI instrument: a product line of compact and versatile cameras designed for high resolution missions in Earth observation, Proc. $7^{\text {th }}$ ICSO Intern. Conf. Space Optics, Toulouse, France, 2008, pp. 14-17.

10. Nghiem V.T., Research on the development of the method for validation and calibration image quality of optical satellite of Vietnam: Report of Scientific Research Project of Ministry of Natural Resources and Environment, Project ID: TNMT2016.08.02, 2017, 56 p.

11. Nghiem V.T., Nguyen M.N., Tran V.A., Do T.P.T., Study method for testing image quality of optical remote sensing satellite of Vietnam, J. Applied Mathematics and Computation, 2018, Vol. 2, Issue 9, pp. 357365, DOI: $10.26855 /$ jamc.2018.09.001. 
12. Nguyen M.N., Tran V.A., Nghiem V.T., Do T.P.T., Method of quality validation for Vietnam's optical remote sensing based on test sites (polygon), Proc. Vietnamese National Science and Technology Conf. Surveying and Mapping, 5 Oct. 2018, Hanoi, Vietnam, 2018, pp. 401-409.

13. SPOT image quality performances, $C N E S, 2004,25$ p., available at: http://www.spot.ucsb.edu/spot-performance.pdf.

14. Valorge C., Meygret A., Lebegue L., Henry P., 40 Years of experience with SPOT in-flight calibration, PostLaunch Calibration of Satellite Sensors: Proc. Intern. Workshop on Radiometric and Geometric Calibration, 2-5 Dec. 2003, Gulfport, Mississippi, USA, S. A. Morain, A. M. Budge (eds.), London: CRC Press, 2004, pp. $117-134$.

15. Viallefont R. F., Removal of aliasing effect on MTF measurement using bi-resolution images, Proc. SPIE Conf. "Sensor, Systems, and Next-Generation Satellites VII", 2003, Vol. 5234, pp. 468-479, available at: https://doi.org/10.1117/12.507273.

16. Viallefont R.F., Léger D., Improvement of the edge method for on-orbit MTF measurement, Optics Express, 2010, Vol. 18, Issue 4, pp. 3531-3545, available at: https://doi.org/10.1364/OE.18.003531.

17. Wenny N. B., Helder D., Hong J., Leigh L., Thome K. J., Reuter D., Pre- and Post-launch spatial quality of the Landsat 8 thermal Infrared sensor, Remote Sensing, 2015, Vol. 7, pp. 1962-1980, DOI: 10.3390/ rs70201962.

\title{
Оценка функции передачи модуляции для изображения вьетнамского спутника VNREDSAT-1 с помощью постоянного испытательного полигона
}

\author{
М. Н. Нгуен ${ }^{1,2}$, В.А. Чан ${ }^{2}$, В. Т. Нгием ${ }^{3}$, Т. Ф. Т. До ${ }^{2}$, С. Х. Чу ${ }^{1}$, Л. Х. Чинь ${ }^{4}$ \\ ${ }^{1}$ Институт космических технологий Вьетнамской академии \\ наук и технологий, Ханой, Вьетнам \\ E-mail:nmngoc@sti.vast.vn \\ ${ }^{2}$ Ханойский горно-геологический университет, Ханой, Вьетнам \\ ${ }^{3}$ Национальный департамент дистанционного зондирования, Ханой, Вьетнам \\ ${ }^{4}$ Технический университет им. Ле Куи Дона, Ханой, Вьетнам
}

Функция передачи модуляции (ФПМ) - это отклик оптической системы на различные синусоидальные пространственные частоты, который определяется как модуль преобразования фурье-функции рассеяния точки. ФПМ - не только важный фактор при оценке качества изображения, но и индикатор для оценки производительности полезной нагрузки на спутнике оптического дистанционного зондирования, особенно для небольших спутников с высоким пространственным разрешением. В статье оценивается работа оптической аппаратуры вьетнамского спутника VNREDSat-1, запущенного 7 мая 2013 г., для чего используются панхроматические изображения с пространственным разрешением 2,5 м. Для оценки ФПМ и, следовательно, производительности VNREDSat-1 применяется классический метод наклонной кромки для постоянного испытательного полигона. Полученные результаты показывают, что качество изображений, получаемых со спутника, было обеспечено в течение расчётного срока его службы (5 лет). Кроме того, для Вьетнама они могут служить основой для завершения разработки правил валидации и калибровки для оптического спутника дистанционного зондирования при наличии собственного испытательного полигона.

Ключевые слова: MTF, качество изображения, VNREDSat-1, испытательный полигон, малый спутник

Одобрена к печати: 06.04.2021

DOI: 10.21046/2070-7401-2021-18-3-81-91

\section{Литература}

1. Blanc P., Wald L. A review of earth-viewing methods for in-flight assessment of modulation transfer function and noise of optical spaceborne sensors // HAL. 2009. Id. hal-00745076. 39 p. URL: https://halmines-paristech.archives-ouvertes.fr/hal-00745076. 
2. Boreman G.D. Modulation Transfer Function in Optical and Electro-Optical Systems. SPIE Press, 2001. 123 p. URL: https://doi.org/10.1117/3.419857.

3. Gascon F., Bouzinac C., Thépaut O., Jung M., Francesconi B., Louis J., Lonjou V., Lafrance B., Massera S., Gaudel V.A., Languille F., Alhammoud B., Viallefont F., Pflug B., Bieniar J., Clerc S., Pessiot L., Trémas T., Cadau E., Bonis D.R., Isola C., Martimort P., Fernandez V. Copernicus Sentinel-2A calibration and products validation status // Remote Sensing. 2017. V. 9. No. 6. Art. No. 584. 81 p. URL: https://doi. org/10.3390/rs9060584.

4. Helder D., Choi T., Rangaswamy M. In-flight characterization of spatial quality of remote sensing imaging systems using point spread function estimation // Post-Launch Calibration of Satellite Sensors: Proc. Intern. Workshop on Radiometric and Geometric Calibration. 2-5 Dec. 2003, Gulfport, Mississippi, USA / eds. S. A. Morain, A. M. Budge. L.: CRC Press, 2004. P. 151-170.

5. Kohm K. Modulation transfer function measurement method and results from Obrbview-3 high resolution imaging satellite // Proc. ISPRS 2004. Istabul, Turkey. 2004. 6 p.

6. Kumar A.S., Manjunath A.S., Rao K.M.M., Kumar A.S. K., Navalgund R. R., Radhakrishnan K. On-orbit spatial resolution estimation of IRS: CARTOSAT-1 Cameras with images of artificial and man-made targetsPreliminary results // Proc. SPIE. 2006. V. 6405. 64050W-1. 7 p. URL: https://doi.org/10.1117/12.697001.

7. Léger D., Déliot P., Valorge C. On-orbit MTF assessment of satellite cameras // Post-Launch Calibration of Satellite Sensors: Proc. Intern. Workshop on Radiometric and Geometric Calibration. 2-5 Dec. 2003, Gulfport, Mississippi, USA / eds. S. A. Morain, A. M. Budge. L.: CRC Press, 2004. P. 67-76.

8. Li H., Yan C., Shao J. Measurement of the Modulation Transfer Function of infrared imaging system by Modified Slant edge method // J. Optical Society of Korea. 2016. V. 20. No. 3. P. 381-388. DOI: 10.3807/ JOSK.2016.20.3.381.

9. Luquet P., Chikouche A., Benbouzid A. B., Arnoux J.J., Chinal E., Massol C., Rouchit P., de Zotti S. NAOMI instrument: a product line of compact and versatile cameras designed for high resolution missions in Earth observation // Proc. $7^{\text {th }}$ ICSO Intern. Conf. Space Optics. Toulouse, France. 2008. P. 14-17.

10. Nghiem V.T. Research on the development of the method for validation and calibration image quality of optical satellite of Vietnam: Report of Scientific Research Project of Ministry of Natural Resources and Environment. Project ID: TNMT2016.08.02. 2017. 56 p.

11. Nghiem V.T., Nguyen M.N., Tran V.A., Do T.P.T. Study method for testing image quality of optical remote sensing satellite of Vietnam // J. Applied Mathematics and Computation. 2018. V. 2. No. 9. P. 357-365. DOI: $10.26855 /$ jamc.2018.09.001.

12. Nguyen M.N., Tran V.A., Nghiem V.T., Do T.P.T. Method of quality validation for Vietnam's optical remote sensing based on test sites (polygon) // Proc. Vietnamese National Science and Technology Conf. Surveying and Mapping. 5 Oct. 2018, Hanoi, Vietnam. 2018. P. 401-409.

13. SPOT image quality performances // CNES. 2004. 25 p. URL: http://www.spot.ucsb.edu/spot-performance.pdf.

14. Valorge C., Meygret A., Lebegue L., Henry P. 40 Years of experience with SPOT in-flight calibration // Post-Launch Calibration of Satellite Sensors: Proc. Intern. Workshop on Radiometric and Geometric Calibration. 2-5 Dec. 2003, Gulfport, Mississippi, USA / eds. S.A. Morain, A. M. Budge. L.: CRC Press, 2004. P. 117-134.

15. Viallefont R.F. Removal of aliasing effect on MTF measurement using bi-resolution images // Proc. SPIE Conf. "Sensor, Systems, and Next-Generation Satellites VII". 2003. V. 5234. P. 468-479. URL: https:// doi.org/10.1117/12.507273.

16. Viallefont R.F., Léger D. Improvement of the edge method for on-orbit MTF measurement // Optics Express. 2010. V. 18. Iss. 4. P. 3531-3545. URL: https://doi.org/10.1364/OE.18.003531.

17. Wenny N.B., Helder D., Hong J., Leigh L., Thome K.J., Reuter D. Pre- and Post-launch spatial quality of the Landsat 8 thermal infrared sensor // Remote Sensing. 2015. V. 7. No. 2. P. 1962-1980. DOI: 10.3390/ rs70201962. 